\title{
The Chronicle of Sultan Agung and the Political Power of the King of Java
}

\author{
Hardyanto $^{1}$, Widodo ${ }^{2}$, Yusro Edi Nugroho ${ }^{3}$ \\ \{hardyantasetyamlaya@mail.unnes.ac.id ${ }^{1}$, widodojawa@mail.unnes.ac.id², \\ yusronugroho@mail.unnes.ac.id $\mathrm{d}^{3}$ \} \\ Universitas Negeri Semarang, Indonesia ${ }^{1}$ \\ Universitas Negeri Semarang, Indonesia ${ }^{2}$ \\ Universitas Negeri Semarang, Indonesia ${ }^{3}$
}

\begin{abstract}
The purpose of this study is to present the chronicle of literature as a media of the power's hegemony of the King of Java. The King as a super figure has extraordinary strengths and qualities. His extraordinary strengths and special qualities have made him worthy to lead the Java Island. This study is a qualitative descriptive research to describe the results of research on The Chronicle of Sultan Agung. The results of the study show that as an Islamic King of Java, his power is legitimized through the text of the chronicle literature. Sultan Agung is narrated as the most benevolent King who is able to conquer many countries without going through war. Charisma and supernatural power proclaimed by the retainer and his subordinates made him respected by officials and kings. At the time of conquering the Cirebon area, by coming to the main city during full moon night while watching puppet shows, the fragrant scent and the flying chair is a form of power hegemony over other countries. Sultan Agung is also able to rule the supernatural creatures. Nyi Roro Kidul is portrayed as a beautiful woman who is fond of Sultan Agung and at the same time also wants to be a wife who devotes herself. The strong feeling and hunch are inherent in Sultan Agung. It is proved by the hunch he got that the British and Dutch troops will arrive in the Land of Java Island. He is also able to go to Mecca in just an instant for Friday prayers in Mecca.
\end{abstract}

Keywords: The Chronicle Literature, Political Power of the King of Jawa.

\section{Introduction}

Writing tradition within the archipelago is a synthesis and deposition of cultural values that exist within the society. Things that have happened can be a determinant in the attitude. It is in line with what has been described [1] that culture is a very important thing in order to determine policies for individuals and for the interests of a nation or country. Culture is formed as the result of the synthesis of past experiences. Old literature contains a variety of lessons, advice, and values that are relevant throughout life. One of the values contained in the codex is the value of leadership. This value is presented in various ways. One of the aspects examined is the value of imaging. According to Weber [2], power is someone who has the ability to lead.

According to its contents, the chronicle can be divided into 4 (four) groups, namely (1) chronicles which describe the opening of a forest area for a royal capital or government centre to be established, like The Chronicle of Majapahit, The Chronicle of Kartasura, The Chronicle 
of Surakarta, and The Chronicle of Mataram; (2) chronicles that focus on matters in a particular area, such as The Chronicle of Banten and The Chronicle of Blambangan, (3) chronicles that tell events in a time series, for example The Chronicle of Palihan Nagari, The Chronicle of Pakepung, The Chronicle of Giyanti, and (4) chronicles which have a wider range of regions and times, for example The Chronicle of Tanah Jawi [3]. According to the form, chronicles are arranged in various prose and various songs (poetry) of macapat (the type of Javanese poetry). When compared, the chronicle is more composed in the form of songs (poetry) of macapat.

Chronicle literature as one of the pillars of political power in the Javanese royal era is characterized by Islam. Chronicles are a form of written work in Java, even one of Javanese literary works [3]. Its function is to hegemony the authorities and also legitimize the rulers through narratives built for the image of their leaders. Literary chronicles contain the genealogy of the king and the people who surround the circle of power. Girardet divided chronicles into chronic groups, legends, and myths. The use of the term chronicle is a model type of historical literature that arose and developed since the end of the 17th century AD, in the era of Kartasura.

Chronicles as historical literary works, can be classified in traditional historiography or local tradition [4], i.e. historical writing compiled traditionally using thought patterns and traditional historical notions. History in this case contains mythical, genealogical, chronic elements. Traditional historiography as historical truth mixed with mystical truth. There is no distinction between the reality of the event that actually happened and the reality of the author's creation [4].

Power related to leaders indirectly shapes the condition of the people. Someone who can be appointed as a leader is a person who has a soul leader and controls the elements of leadership. A person who has a position or has been known as the highest person in the community. Society must be subservient to what has been set by the government.

Through literature the Javanese functionaries gave doctrine to their literate people to echo through literary power. As not all people can read, the majority of the literature is created in the macapat meter. The goal is to be able to be delivered verbally in events organized by the wider community. Ways and tactics of the propaganda of literary power are able to reach the roots to touch the lowest layers of society. The dominance of power not only affects certain communities and certain groups but also the various layers of society they lead.

Sultan Agung in the Chronicle of Sultan Agung legitimizes power through literature. In addition to describing exemplary, supernatural powers, and also fairness, the chronicle also places power on the power possessed. The king was able to communicate with supernatural beings to support and sustain the perpetuity and authority.

\section{Research Methods}

This research used a qualitative descriptive method. According to Ratna (2015), methods in the broadest sense are ways or strategies to understand the real situation, systematic steps in solving problems. According to Yusuf [5] the analysis of data used narrative analysis. The research aims to parse the results based on research conducted by the researchers. The data collected in the form of words or portrayal of something objectively.

The purpose of this research is to give meaning to natural conditions that are important to the object of the study. According to Rukajat [6], the use of a qualitative approach as the research approach is because the researchers see the nature of the problem under the study can develop naturally in accordance with the conditions and situations at the location. 


\section{Findings and Discussions}

The power of the King of Java in the context of the chronicle was the golden age of the Islamic kingdom. The king is the head of government and the kalifatullah umat (God's representative). His words and commands are laws that all subjects must obey. To realize this, the great Sultan of the great king of Mataram legitimized his power with a chronicle literature. Nobleness, supernatural powers, strengths and abilities above ordinary people are built in the frame of literary chronicle.

Sultan Agung is described as a supreme king who has extraordinary qualities. Metaphorically, people believe they will get karma by only talk about him. The author presented the narrative of him as a king who has strength that cannot be measured with anything. All the magic of knowledge merges in the soul of Sultan Agung. The following excerpts are the superior forms of Sultan Agung who are able to govern the occult and at the same time become servants and friends.

"Krana mangke ing banten sultani, dereng nungkul katon, ya ta jeng Sultan Agung tindake, nitih amparan sinunggi dening, pun juru taman mring, akasa kras mumbul. Tindakira wanci surup samsi, ing waryang blas awor, rawuh dalem ing banten wancine, bakda magrib dadya den lampahi, setunggal jam gya prapti, banten sing mentarum. (BS. Mijil-15-16).”

"Sultan Agung went to Banten because the kingdom had not surrendered to Mataram. Sultan Agung left by riding the keprabon chair carried by a park interpreter who had become a fine creature. Instantly go up into space, he left before maghrib as the sun set and arrived in Banten right after sunset. Within one hour Mataram arrived in Banten."

In the fragment of the pupuh mijil on the 15th and 16th, Sultan Agung, assisted by his servant, went to Banten in just one hour. This is an advantage of Sultan Agung who was able to do things beyond human reason at that time. People can travel hundreds of kilometres in the blink of an eye. In addition, the king is also able to rule the subtle creatures that are visible to help his journey. So that the naked eye of the Banten people in the next stanza was that the king of Mataram was able to fly in his chair and land in the square of Banten which was holding a puppet show. At the time he was landing, the flying chair looks radiant by emitting and pervading smell as fragrant, whose fragrance can be felt by the sense of people from all over the country.

"Gunging janma sa-Banten nagari, kagyat gawok-gawok, mambet ganda sru manjing granane, muleg manjing sanubari, wrin sajroning puri, ing banten sakamu."

"Everyone in Banten State was amazed to smell the sweet smell that stung into the nose to penetrate the hearts of the people of Banten."

All the people of Banten were amazed because of the advantages possessed by the King of Mataram. It also smells very fragrant. For the size of a normal person, this is certainly not the case. What is said in the quote is a form of hegemony over the power and ability of Sultan 
Agung in conquering people's charisma. Indirectly with this description, Sultan Agung was a king who did not like to have a war with his fellow men in expanding his colony. He conquered the area outside of power with the most intelligent tactics not with bloodshed. Even though Banten had not been surrendered directly but with the presence of the king in the square in an improper manner, he was worthy of a higher position than the King of Banten.

\subsection{Patron Politics}

Javanese leadership always requires political patrons in every era of government. In the period of Islam which was honoured by the King Sultan Agung was also being a patron for the officials and his subordinates. The government of Java in the Islamic era presented the king who also becomes kalifatullah fil ardi (the community leader). He got the nickname of Sayidin Panatagama, which means the King has qualities that come from the high God of Mercy Gusti Allah.

"Salat aning kakbatullah, yen tindak salat sang aji, pangkatnya ji jam sewelas, pulangnya pukul satunggil, dadya nafri mentawis, lan mekah dwi jam duhipun, sajroning kalih jam, wus rampung perlu lan wajib, wajib ira kang kinarasan jroning mala. Mila jeng sultan mataram, lajeng ajejuluk menggih, khalifah ywang prabu sultan, agung nyakrakusumadi, jumeneng neng mentawis, dene ta kawentaripun kaloka lyan praja, nagari ing pundi pundi, ngatas angin bawah angin wus sumewa." --Sinom pada 24-25-193

"Praying in front of $K a^{\prime} a b a$, he departs at eleven o'clock and goes home at one o'clock. Mataram to Mecca in just two hours, just right after the sunnah is complete and must be felt in the heart. So that is why the Sultan of Mataram was calleded as the khalifah Ywang Prabu Sultan Agung Nyakrakusuma reigned in Mataram, while his reputation in other kingdoms was no doubt."

The excerpt in addition to presenting the awesomeness of the ability in psychology and his strengths, is also presenting the King as one who is able to worship to the closest place he is blessed. This was intended in the king's excess narrative so that the people he led became easy to be taken care of and controlled because those who controlled and led them are only extraordinary people. Besides that, the narrative is also at the same time being as a propaganda of Religion to those who have not entered Islam at that time.

\subsection{Powerful and Faithful}

Sultan Agung as a great king also has a very faithful and powerful spells. Panembahan Purbaya as the patih (governor) has supernatural powers that cannot be logically reasoned. Besides Panembahan Purbaya, there are still many others who are very loyal as the governor. The subordinates are also very obedient like Pangeran Jakarta and the regent of the northern coastal region of Java. The following quotation is the evidence that the news of Panembahan purboya's supernatural power has up to the country far across the sea, i.e. until in Palembang.

"Nging teksih pradondi karsa, kalawan rekyana patih, sanget sanget pamambengnya, "reh suseno myarsa warti, kaprawiraning ajurit, sagung prawira mataram, kasektenira miwah, ingkang dadya senopati, ramtamira panembahan 
purbaya. Twin kang para sentana, sedayanya sekti, nadyan pekathiknya pisan, teguh timbul ing jurit, tumemplek katiban mimis, braja tugel myang mangkeluh, punika pekathiknya, witipun kang senopati, yen tinegor kuciwanya dadya toya." 3132-194 Sinom.

When the king was still debating with the governor, he was so angry at hearing the news of the Mataram soldier's power, the prolific greatness of Panembahan Purbaya and also the soldiers who all have the power. Although he is only a governor, but he has a warrior character who is immune to bullets and broken arms if it is about him and is able to turn into water when he is being chopped.

"Panembahan purbaya nuli leyangan, mriyem ageng pribadi, gya gepeng mriyemnya, mingkem bolonganira, mriyem dadya lempung nuli, sedaya jalma, palembang aningali, Sami gumun sami ngungun manahira, jleg jumbleg kethip kethip, ana ngalam donya, padha durung uninga, mriyem gepeng den leyangi, jeng panembahan, purbaya sigra ngalih. Durma 25-26-197.

"Panembahan Purbaya then leaned on the cannons alone, when instantly the tip of the cane hole is being gepeng (flat). Covering the hole is even a cannon that turns into clay. All the people in Palembang are watching. Everyone was astonished and in their heart it is regarded as impossible. During living in the world, it is only now they know that the gun can be flat only by being used for leaning. Panembahan Purbaya soon moved."

Apart from the King of Mataram, there are also many powerful persons who not everyone can match. Panembahan Purbaya as a trusted person of the King also has the power that makes people in Palembang are impossible.

"Kumpeni kang aning palwa, sadayanya sami mangati-ati, mariyem sinulat sampun, nanging jeng panembahan, datan kandheg ingkang palwa nander asru, ngadeg lir deg saka lanang, warnanira nggegilani, Baita saksana nunjang, angin sanget swara saingga bedhil, sangking barat sanget nempuh, swaranira lir gelap, baitane wong walanda sampun remuk, karem aneng jro samudra, ingkang kari sampun lari. Pangkur 18,19-439.

The foreigners on board were all careful. The cannon was turned on but Panembahan Purboyo's boat continued to go fast. He stood like a monument with a terrible form. The ship immediately crashed. A roar like a storm from the west was very strong like a thunder. Dutch ships were destroyed and sank in the ocean. The others left him. The word mingkem bolonganira which means being able to close the cannon hole made of chosen iron by only leaning on it. The next verse also describes the supernatural powers of Panembahan Purbaya which can bring strong winds that make waves of sea water so that the Dutch ship sinks. Swaranira lir gelap's voice like the tempest comes beyond the sound of cannons and gunfire. From the excess, the Dutch ship ran away from Sunda Kelapa Port.

As the King of Java, leadership leaders in Java have at least three main points as figures, i.e. having a fair, true and honest character. Fair, as a king, he must be able to bring justice to the people without exception. If the king is able to be fair, then in governing he will not have difficulty in doing what is according to the rules and correct according to the applicable legal 
order. The third point as a leader, the king must have an honest character in saying and doing for the prosperity of the people who trust him. If those three points are able to be presented by a leader, it is not impossible that a king is not just a feudal who is feared by opponents and subjects but is able to become a patron and role model.

The correlation with political dynamics in the democratic era is the conceptual similarity. Although in two different systems, but in politics, leadership has similarities. If the era of the Javanese Islamic empire was feudal in nature and what was said by the king was law, then the era of democracy is the era which the word of law is not from the leader but the leader has to obey the applied rules they have set.

The similarity between the democratic and feudal era is the need for political synchronization of power in leadership. The people need a figure who is capable of being exemplified, not feared or built on imagery that seems good, but in full of negative intrigue to perpetuate power.

\section{Conclusion}

Sultan Agung as a King of Java is a king who legitimized his authority with the literary chronicle of Sultan Agung. He is the great king who is capable of conquering another country without war. Charisma and supernatural power proclaimed in the text related to the king, retainer and subordinates make him respected by foreign officials and kings. The strong feeling and hunch which are inherent in Sultan Agung appear on the premonition of the arrival of English and Dutch people in the land of Java. He is also able to go to Mecca for Friday prayers in the blink of an eye.

\section{References}

[1] A. R. Hidayat, "Citra Kepemimpinan dalam Sastra Lama; Hikayat Sri Rama dan Wawacan Babad Timbanganten," METASASTRA J. Penelit. Sastra, vol. 1, no. 1, pp. 18-25, 2017.

[2] A. R. Wijakangka, "Analisis Hegemoni Kekuasaan Dalam Novel Pabrik Karya Putu Wijaya,” J. Artik., vol. 5, no. 1, 2013.

[3] Soedarsono, Keadaan dan Perkembangan Bahasa, Sastra, Etika, Tatakrama, dan Seni Pertunjukan Jawa, Bali, dan Sunda. Yogyakarta: Javanologi, 1985.

[4] E. S. (ed) Ekadjati, Direktori Naskah Nusantara. Jakarta: Yayasan Obor Indonesia., 2000.

[5] A. M. Yusuf, Metode penelitian kuantitatif, kualitatif \& penelitian gabungan. Prenada Media, 2016.

[6] Ajat Rukajat, Pendekatan Penelitian Kualitatif. Yogyakarta: Penerbit Deepublish, 2018. 